\title{
New Hampshire's Estimated Population Gain Is the Largest in New England
}

Kenneth M. Johnson

1 The population of New Hampshire grew by 5,500 (0.4 percent) to 1,366,000 between July of 2019 and July of 2020, according to new Census Bureau estimates. This was the largest population percentage increase in New England. In contrast, the region as a whole and four of its six states lost population between July 2019 and July 2020, due in part to mortality associated with the COVID-19 pandemic. New Hampshire's population percentage increase has been the largest in New England in each of the last three years. New Hampshire and Maine gained population in each of the last four years, and Massachusetts grew in three of the four years. In contrast, Connecticut, Rhode Island, and Vermont all lost population in at least three of the last four years. All of New Hampshire's population gain in recent years has been due to migration, as recent Carsey research shows there have been fewer births than deaths in the state. Maine and Vermont also had more deaths than births in recent years. This is likely to continue in the near-term because of mortality increases associated with COVID-19. Both New Hampshire and New England's overall population gain during the past four years has been considerably smaller than gains in many states in the south and west.

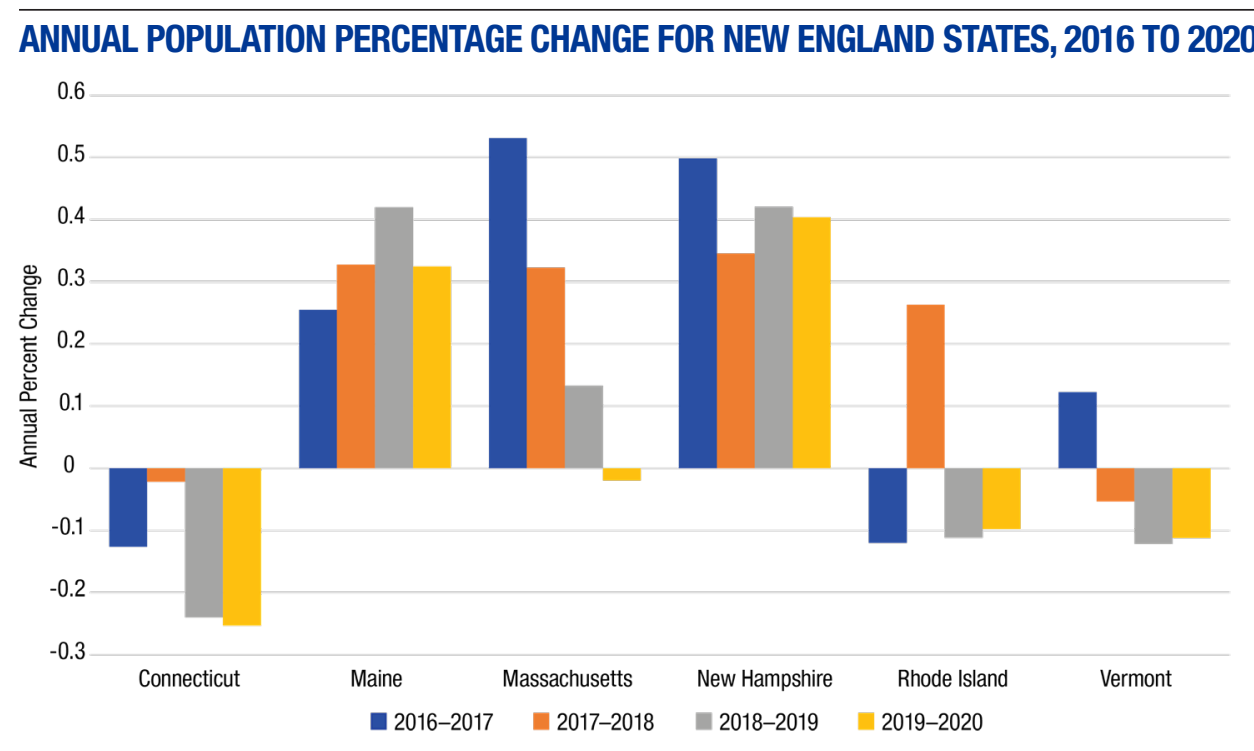

Analysis: K.M. Johnson, Carsey School, University of New Hampshire. Source: U.S. Census Bureau Population Estimates released 12/22/20. Note: This analysis is based on population estimates and should be interpreted with caution.
介I

Last year, New Hampshire's population grew by the largest percentage in New England, continuing a three-year pattern.

\section{See Related Publications at carsey.unh.edu}

- Migration Gains to New Hampshire From Other U.S. States Are Growing, With the Largest Gains Among Young Adults (December 2020)

- New Hampshire Population Grew Last Year, Even Though Deaths Exceeded Births (January 2020)

About the Author
Kenneth M. Johnson is senior
demographer at the Carsey
School of Public Policy, Class of
1940 professor of sociology at
the University of New Hampshire,
and an Andrew Carnegie Fellow.
His research was supported by
the New Hampshire Agricultural
Experiment Station in support of
Hatch Multi-State Regional Project
W-4001 through joint funding of
the National Institute of Food and
Agriculture, U.S. Department of
Agriculture, under award number
1013434, and the state of New
Hampshire. The opinions are his
and not those of the sponsoring
organizations.

\section{About the Author}

Kenneth M. Johnson is senior demographer at the Carsey School of Public Policy, Class of 1940 professor of sociology at the University of New Hampshire, and an Andrew Carnegie Fellow. His research was supported by the New Hampshire Agricultural Experiment Station in support of Hatch Multi-State Regional Project W-4001 through joint funding of the National Institute of Food and Agriculture, U.S. Department of Agriculture, under award number Hampshire. The opinions are his organizations.
Huddleston Hall • 73 Main Street • Durham, NH 03824 carsey.unh.edu • 603.862.2821
TTY UsERS: DIAL 7-1-1 OR

1-800-735-2964 (RELAY N.H.) 